\title{
THE INFLUENCE OF AIR TEMPERATURE DIVERSITY IN CENTRAL EUROPE ON THE OCCURRENCE OF VERY STRONG AND EXTREME COLD STRESS IN POLAND IN WINTER MONTHS
}

\author{
Małgorzata Owczarek \\ Faculty of Oceanography and Geography \\ University of Gdańsk \\ Bażyńskiego 4, 80-309 Gdańsk: Poland \\ e-mail: malgorzata.owczarek@ug.edu.pl
}

\begin{abstract}
The aim of this research was to illustrate the relationship between the occurrence of very strong and extreme cold stress among human beings under the Universal Thermal Climate Index (UTCI) across Poland and largescale near-surface air temperature over the central part of Europe. The statistical downscaling procedure of canonical correlation analysis (CCA) with respect to the period between 1971 and 2000 was applied to extract the main modes of large-scale factors and their local responses. The greatest frequency of occurrence of the discussed cold stress exceeded $35 \%$ in January. Most of the variance (39-44\%) of the local field in each winter month is explained by the first coupled canonical maps. The main patterns of large-scale field show negative anomalies of monthly mean air temperature in central Europe from $-1^{\circ} \mathrm{C}$ up to $-3^{\circ} \mathrm{C}$. It can indicate an increase in frequency of the occurrence of analysed cold stress categories throughout the entire area of Poland, by $2 \%$ to even over $10 \%$, depending on the region. The best quality model was obtained in eastern Poland, especially in the north-east and south-west of Poland.
\end{abstract}

\section{Key words}

bioclimate - Poland - cold stress - Universal Thermal Climate Index (UTCI) - air temperature - canonical correlation

\section{Introduction}

The meteorological conditions and the climate features incessantly affect the human body and human well-being. The impact of weather conditions is manifested primarily by the formation of 'bio-thermal environment'. This term encompasses both the atmospheric heat exchange with the human body and the organism physiological response (Błażejczyk et al., 2013). The atmospheric conditions of heat exchange are shaped by a combinate of meteorological variables: radiation, air temperature, air movement and air humidity. 
This is important particularly in the case of conditions inducing strong thermal stress on human beings. In a cold stress condition, thermoregulatory mechanisms are directed to the reduction of heat loss from the body (Holmér, 1988). They result in narrowing of blood vessels and increase in blood pressure. There is a risk of hypothermia, heart failure, myocardial infarction or even death following the excessive heat loss from the body (Kuchcik, 2017, 2020). In the case of deaths associated with cold thermal conditions, in contrast to the deaths associated with the occurrence of heat stress, their increase is recorded faster, as early as 2 days after a sudden decrease in air temperature, but the maximum number of cases usually appears with a delay, within 30 days (Keatinge, 2002; Laschewski \& Jendritzky, 2002). The analysis of death risk in Warsaw showed $32 \%$ increase during very strong cold stress conditions (Błażejczyk et al., 2015; Kuchcik, 2017). Moreover, negative effects of cold stress can often be accompanied by a higher risk of seasonal infection (e.g. influenza) and other factors, such as demographic and socioeconomic conditions (Laschewski \& Jendritzky, 2002; Kuchcik, 2017). The risk of negative effects of cold stress also varies depending on the general climatic conditions. This is due to poorer adaptation to cold conditions among people in temperate climate regions than in the regions with severe winters (Gasparrini et al., 2015). The effect of adaptation is also visible in studies taking into account many cities in one country (Kuchcik, 2017, Kuchcik et al., 2021). Air temperature is the essential component of bio-thermal environment. The studies of long-term changes in the thermal conditions in Poland indicated an increase in the average air temperature in winter and a decrease in the number of days with extremely low air temperature and cold waves (Wibig, 2007; Wibig et al., 2009; Owczarek \& Filipiak, 2016; Tomczyk et al., 2021). However, hazards associated with cold thermal environment does not disappear, e.g., 2009/2010 winter in Europe can be considered as an example of cold extreme superimposed on a warming climate (Cattiaux et al., 2010). Central Europe experienced extremely cold conditions in the winter of 2011/2012, which resulted in more than 800 deaths due to hypothermia in Central and Eastern Europe (Lhotka \& Kyselý, 2015). Very low values of air temperature were recorded in Poland even during relatively warm winter seasons of 2016/2017 and 2017/2018 (Tomczyk et al., 2019a). Therefore, taking into account the above-mentioned changes in the thermal conditions in Poland, indicating the possibility of sudden and short-term periods with low air temperature, studies on the conditions of the occurrence of cold stress are of particular importance. Many thermal stress indices have been defined and used to assess bioclimatic conditions for human beings (Błażejczyk et al., 2012). The Universal Thermal Climate Index (UTCI) is one of the most appropriate indices for applications in human biometeorological studies (Jendritzky et al., 2012; Staiger et al., 2019). It was derived from the advanced and comprehensively validated multi-node Fiala model of human temperature regulation and thermal comfort (Fiala et al., 2012; Błażejczyk et al., 2012). The UTCI is defined as the air temperature of reference environment that would provide the same physiological response of a reference person as the actual environment (Błażejczyk et al., 2012; Jendritzky et al., 2012). The UTCI has been commonly applied in biometeorological research related to various spatial and temporal scales in different regions, e.g., in Europe as a whole (Błażejczyk et al., 2015a; Di Napoli et al., 2018), Germany (Matzarakis et al., 2014), Czech Republic (Novak, 2013; Urban \& Kyselý, 2014; Lehnert et al. 2020), Italy (Petralli et al., 2020), Russia (Vinogradova, 2020), Canada (Provençal et al., 2016), Brazil (Bröde et al., 2013; Krüger et al. 2020), China (Ge et al., 2017). The first results of a new micrometeorological model with a biometeorology module to calculate UTCI (Fröhlich \& Matzarakis, 2020) were recently presented by Geletič et al. (2021). The spatiotemporal patterns of thermal exposure in a moderate-climate urban area were per- 
formed for a domain in Prague. The UTCI across Poland has been analyzed (Błażejczyk \& Kunert, 2011; Błażejczyk et al., 2015b; Kuchcik 2017, 2020; Owczarek, 2019; Tomczyk \& Owczarek, 2020; Krzyżewska et al., 2020; Wereski et al., 2020; Kuchcik et al., 2021). The index has been also used to assess bioclimatic conditions in different regions in Poland (e.g., Nowosad et al., 2013; Milewski, 2013; Kolendowicz et al., 2018; Błażejczyk et al. 2020; Głogowski et al., 2020) and in Polish cities (e.g., Błażejczyk et al., 2016; Bryś \& Ojrzyńska, 2016; Bartoszek et al., 2017; Okoniewska, 2020; Kuchcik et al., 2021). The UTCI is calculated, in large measure, based on the temperature value and represents air temperature of the reference condition with the same physiological response as the actual condition. From a longer perspective, the regional-scale variability of air temperature and its impact on variability of biothermal conditions is important. One should also remark that air temperature is the primary variable used to classify the global climate. Most of classifications, such as the most frequently used Köppen-Geigen climate classification, makes a quite effective description of the climate global variability based on the thermal regimes (Błażejczyk et al., 2015a). Thus, the use of air temperature as a largescale factor provides an opportunity to take into account the thermal impact of the further-away areas on bioclimatic conditions. The aim of this study is to find connections between the occurrence of very strong and extreme cold stress under the UTCl in Poland and the regional air temperature field. It allows the derived statistical model to be useful to describe bioclimatic conditions in Poland in winter months.

\section{Data and methods}

To prepare the analysis of the occurrence of strong and extreme cold stress based on the UTCl in Poland, long data series recorded at 45 meteorological stations (high mountains were excluded) for the period between 1951 and 2010 were used (Fig. 1).
Only three series were incomplete: the data of Rzeszów is available for the period from 1952 and of Nowy Sacz and Lesko - for the period from 1954 The abovementioned series were obtained from certified database of the Institute of Meteorology and Water Management - National Research Institute. The applied data meets the requirements in terms of good quality. Everyday values of air temperature $\left({ }^{\circ} \mathrm{C}\right)$, relative humidity $(\%)$, wind speed $\left(\mathrm{m} \cdot \mathrm{s}^{-1}\right)$, and total cloudiness (oct.) at 12:00 UTC were used to calculate the UTCl values. This time of day corresponds to most types of outdoor human activity in Poland (Kuchcik, 2020). The air temperature $\left({ }^{\circ} \mathrm{C}\right.$ ) at $2 \mathrm{~m}$ above ground over the central part of Europe $\left(42.5^{\circ} \mathrm{N}-62.5^{\circ} \mathrm{N}\right.$ and $\left.5^{\circ} \mathrm{E}-32.5^{\circ} \mathrm{E}\right)$ was characterized by anomalies calculated based on the data obtained from the relatively commonly used data NCEP/NCAR Reanalysis (Kalnay et al., 1996) with spatial resolution of $2.5^{\circ}$ latitude and $2.5^{\circ}$ longitude.

As mentioned above, the UTCl is defined as the air temperature of the reference conditions which produces the same response index value. The meteorological reference conditions are as follows: the mean radiant temperature equals the ambient temperature, the wind speed observed $10 \mathrm{~m}$ above ground is $0.5 \mathrm{~m} \cdot \mathrm{s}^{-1}$, and the reference vapor pressure corresponding to $50 \%$ relative humidity for ambient temperature equals at most $29^{\circ} \mathrm{C}$. In physiological reference conditions a metabolic rate while walking at the speed of $1.1 \mathrm{~m} \cdot \mathrm{s}^{-1}$ equals $135 \mathrm{~W} \cdot \mathrm{m}^{-2}$ and clothing insulation meets the current thermal conditions and wind speed. In the present work, the UTCl was calculated with the use of BioKlima 2.6 software package (Błażejczyk \& Błażejczyk, 2006) with implemented computing formula of the mean radiant temperature $\left({ }^{\circ} \mathrm{C}\right)$. Absorbed solar radiation $\left(\mathrm{W} \cdot \mathrm{m}^{-2}\right)$ was calculated from SolAlt model (Błażejczyk, 2005) depending on total cloudiness (oct.) and solar elevation angle $\left({ }^{\circ}\right.$ ). The longwave outgoing surface radiation $\left(\mathrm{W} \cdot \mathrm{m}^{-2}\right)$ was estimated on the base of total cloudiness (oct.) and air temperature $\left({ }^{\circ} \mathrm{C}\right)$. Longwave back radiation emitted by atmosphere was calculated using 


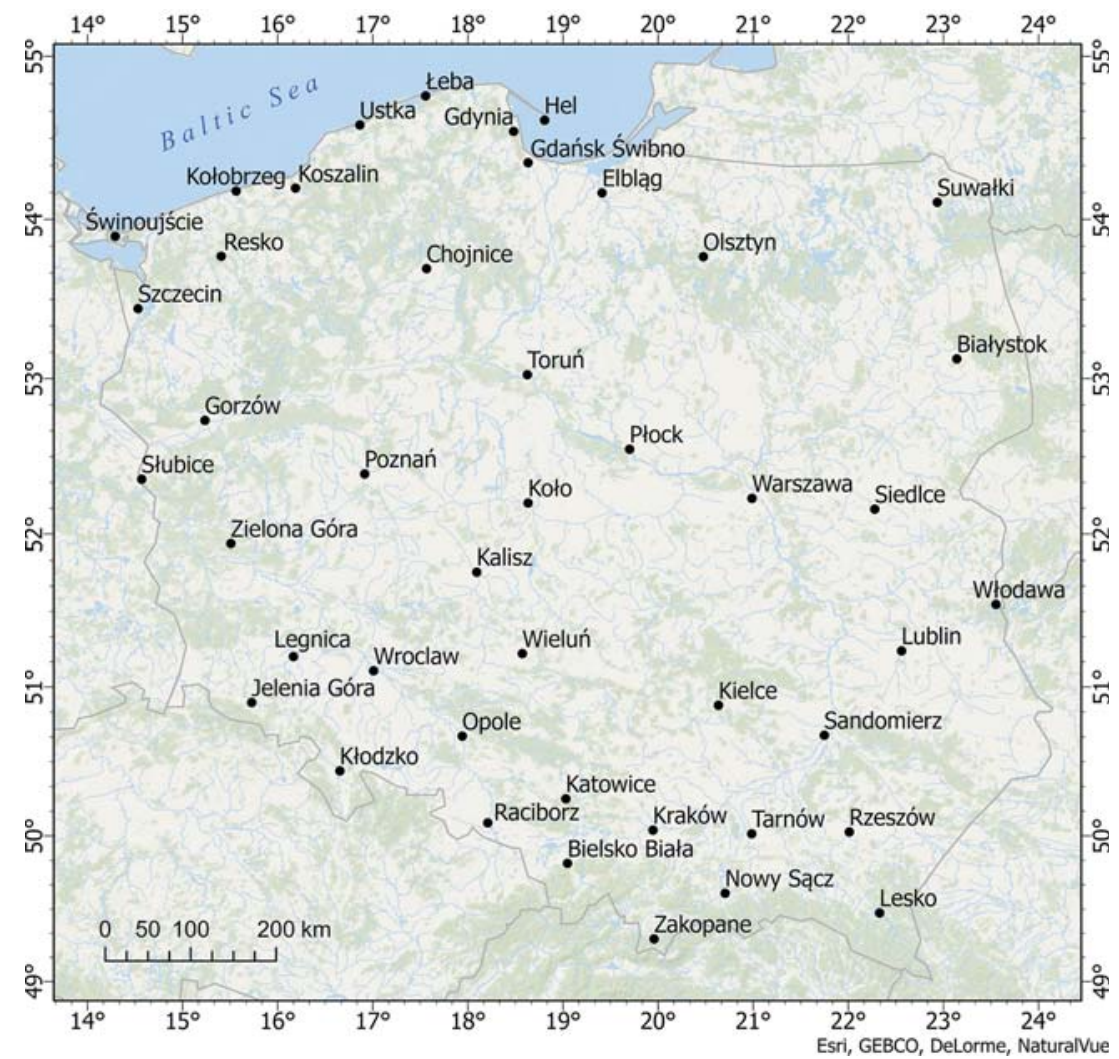

Figure 1. Location of the meteorological stations used in the study

values air temperature $\left({ }^{\circ} \mathrm{C}\right)$ and vapor pressure $(\mathrm{hPa})$. Formulas for calculating the variables are clearly defined in Błażejczyk (2005) and Błażejczyk \& Kunert (2011). Then, the daily and monthly frequencies of the occurrence of very strong and extreme cold stress were determined in line with the assessment scale of the UTCl values classified in terms of thermal stress (Bröde et al., 2012). To construct the scale the UTCl, threshold values for the occurrence of critical levels of thermal stress reactions in human beings were identified (Błażejczyk et al. 2010; Bröde et al. 2012). The very strong cold stress UTCl threshold value equals $-27^{\circ} \mathrm{C}$, facial skin frostbite may occur within 120 minutes. It is recommended to use warmer clothing and to reduce outdoor exposure time. As the value of the UTCI decreases, further physiological responses are observed, e.g., numbness of facial skin and shivering at $-32^{\circ} \mathrm{C}$, the risk of frostbite is increasing. The extreme cold stress UTCl threshold value equals $-40^{\circ} \mathrm{C}$, face skin frostbite can occur within 30 minutes and it is recommended to stay indoor. The relationship between the variability of the occurrence of very strong and extreme cold stress in Poland and the air temperature regional field was examined using a statistical downscaling tool, the canonical correlation analysis (CCA). The CCA analysis allows to find the best linear combination between two multidimensional vectors of the large-scale factor (predictor) and local-scale response field (predictand), and to select pairs of patterns (canonical maps) of spatial and temporal-dependent variables so that their coefficient time series are optimally correlated (Barnett \& Preisendorfer, 1987; Werner \& von Storch, 1993). This method was 
described in detail in the works of Barnett \& Preisendorfer (1987), von Storch \& Zwiers (1999) and Wilks (2005). The CCA method has been most commonly applied to identify the coupled modes of large-scale variables and local fields of various air temperature indexes (Benestad, 2002; Tomozeiu et al., 2018) and precipitation indexes (Santos et al. 2007; Busuioc et al., 2008). The largescale circulation sea level pressure, geopotential height at $500 \mathrm{hPa}$, air temperature at $850 \mathrm{hPa}$ as well as air temperature at $2 \mathrm{~m}$ above ground were most often used as predictors. However, biometeorological variables has not been widely used as predictands. Most often they were the phenological characteristics (Maak \& von Storch, 1997; Matulla et al., 2003; Santos et al., 2012). The CCA was applied to find connections between the occurrence of heat load among human beings across Poland and atmospheric circulation over the North Atlantic Ocean and Europe as well as air temperature at $2 \mathrm{~m}$ above ground over central Europe (Owczarek, 2019). In the present study, the CCA with respect to the period between 1971 and 2000 was applied to find the main modes of large-scale near-surface air temperature and its local response. The air temperature $\left({ }^{\circ} \mathrm{C}\right)$ at $2 \mathrm{~m}$ above ground over the central part of Europe was chosen as a predictor. The monthly frequency of the occurrence (\%) of very strong and extreme cold stress in Poland became the predictand. The reconstructed series of the frequency of occurrence of very strong and extreme cold stress in Poland between 1951 and 2010 were determined. The validation of the constructed model was performed using independent data series covering the periods between 1951 and 1970 as well as 2001 and 2010. The maximum number of canonical map pairs was taken into account. The correlation coefficient between the modelled and observed values of the frequency of occurrence of very strong and extreme cold stress as well as the root mean square error (RMSE) were calculated.

\section{Results}

The frequency of occurrence of the UTCI index ranges that represents very strong and extreme cold stress among human beings under the observational series over the period between 1951 and 2010 in winter months generally increases from the west to the east (except for the mountains). Such a variability reflects the impact of the Atlantic Ocean: bioclimatic conditions become more severe as the distance increases. The greatest frequency of occurrence of the discussed cold stress can be observed in the north-eastern part of Poland. It exceeded 25\% in December (Fig. 2A), 30\% in February (Fig. 2C) and $35 \%$ in January (Fig. 2B) corresponding to even 11 days per month. In western Poland it can be observed approximately within 3 to $10 \%$ of cases in January and less than 5\% in December and February. The mitigating effect of the waters of the Baltic Sea in winter is not as clearly visible as in the case of spatial variability of air temperature. The coastal stations usually record the highest values of average seasonal air temperature as its values decrease gradually with increased distance from the coastline (Owczarek \& Filipiak, 2016). The longitudinal increase in the frequency of occurrence of very strong and extreme cold stress can be observed also on the coast. This indicates that the thermal stress on the coast is subject to the cooling effect of wind. It is noticeable especially in the eastern part of the coast. In turn, relatively low frequency of occurrence of very strong and extreme cold stress (below 5\%) can be observed in foothills of the Carpathians. It probably refers to the advections of warm air from the south, particularly during local orographic wind phenomenon. The impact of relief on wind speed mitigation during daytime can also be observed.

The influence of large-scale air temperature field on the occurrence of very strong and extreme cold stress among human beings in Poland was investigated by applying the CCA. To estimate the abovementioned 

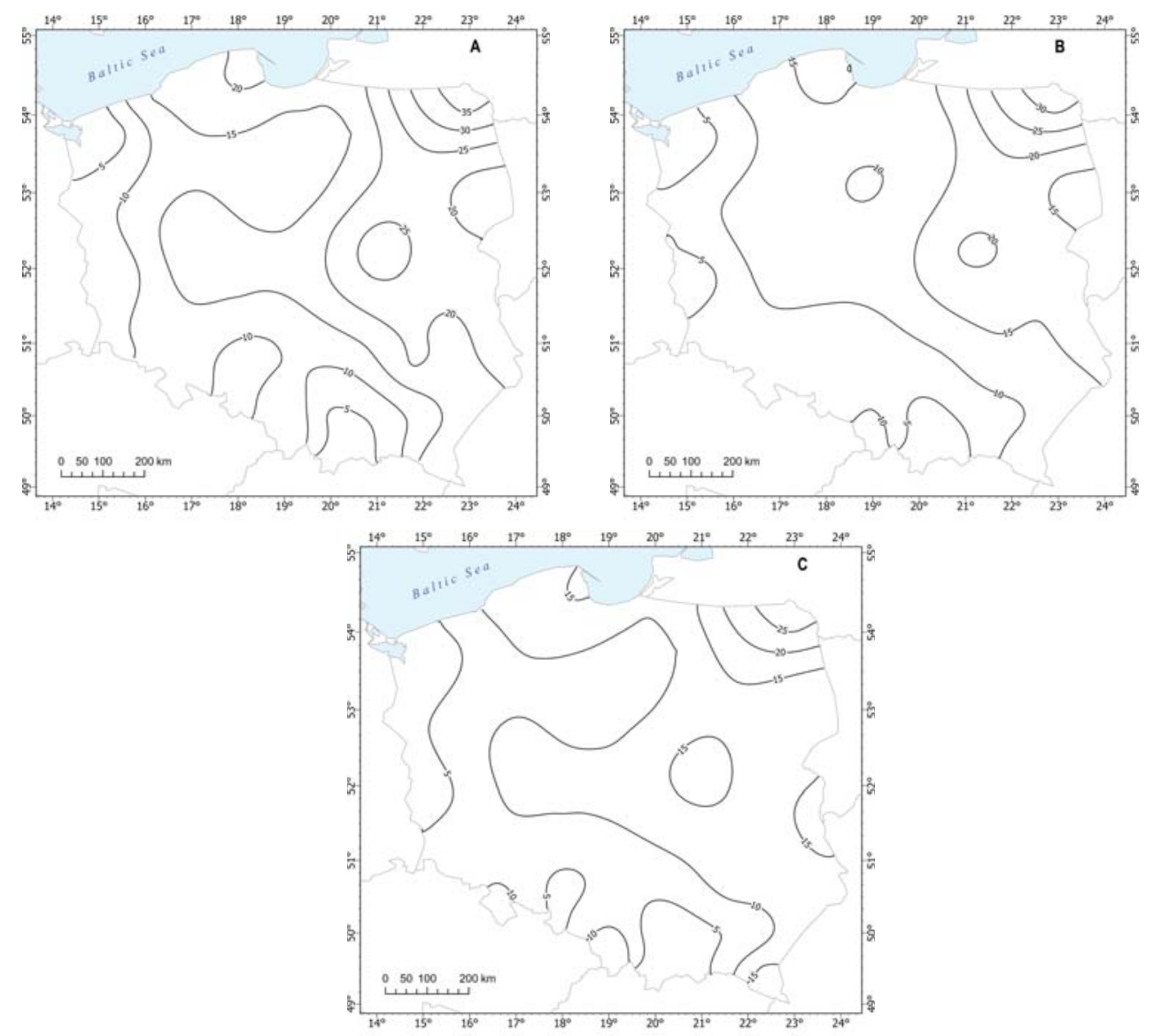

Figure 2. Monthly mean frequency of occurrence (\%) of very strong and extreme cold stress based on the Universal Thermal Climate Index (UTCI) in Poland in January (A), February (B) and, December (C), 1951-2010

relationship, 6 pairs of canonical patterns were obtained in December as well as in January and 5 pairs in February. Most of the variance of the local field in each winter month is explained by the first coupled canonical maps. The first CCA in January reveals negative values of anomalies in air temperature, decrease from the southwest to the northeast. The mode shows the area of the lowest negative values of air temperature anomalies, lower than $-3^{\circ} \mathrm{C}$, localized over eastern Europe. The anomalies of air temperature in much of Poland was approximately $-2^{\circ} \mathrm{C}$ and are lower than $-2.5^{\circ} \mathrm{C}$ in the eastern part of the country. One can assume that the presence of cool continental air masses from the east and north-east have caused a decrease in monthly mean air temperature. It results in the increased frequency of the occurrence of analysed cold stress categories throughout the entire area of Poland, even up to over $10 \%$. This mode explains over $43 \%$ of the variance of the monthly frequency of occurrence of strong and extreme cold stress field and over $57 \%$ of the variance of the air temperature field at $2 \mathrm{~m}$ over central Europe. The canonical series are very well correlated (0.96). The close relationship between low regional-scale air temperature at $2 \mathrm{~m}$ and positive anomalies of the frequency of strong and extreme cold stress in Poland is also shown by the first coupled mode 
in February. The negative anomalies of monthly mean air temperature were visible throughout Poland. The spatial extent of the values of anomalies above $2.5^{\circ} \mathrm{C}$ reached as far as northern Germany. The local map presents positive values of the analysed variable, which indicates an increase in the frequency of cold stress of 2 to $4 \%$ in the west and south regions of Poland, up to over $8 \%$ on the eastern part of the coast and over $10 \%$ in the east. The mode explains $44 \%$ of the variance of the local variable field and over $58 \%$ of the variance of large-scale field. The canonical correlation equals 0.95 . The first coupled canonical map in December explains $39 \%$ of the variance of the local field and $20 \%$ of the variance of large-scale field; canonical series are characterized by a high correlation coefficient (0.95). The pattern of large-scale field shows monthly mean air temperature not spatially differentiated throughout Poland; negative values of anomalies are not lower than $-1^{\circ} \mathrm{C}$. However, over the northern half of the Baltic Sea and partly over the southern Scandinavian Peninsula the values of anomalies are lower than $-1.1^{\circ} \mathrm{C}$. In consequence, the

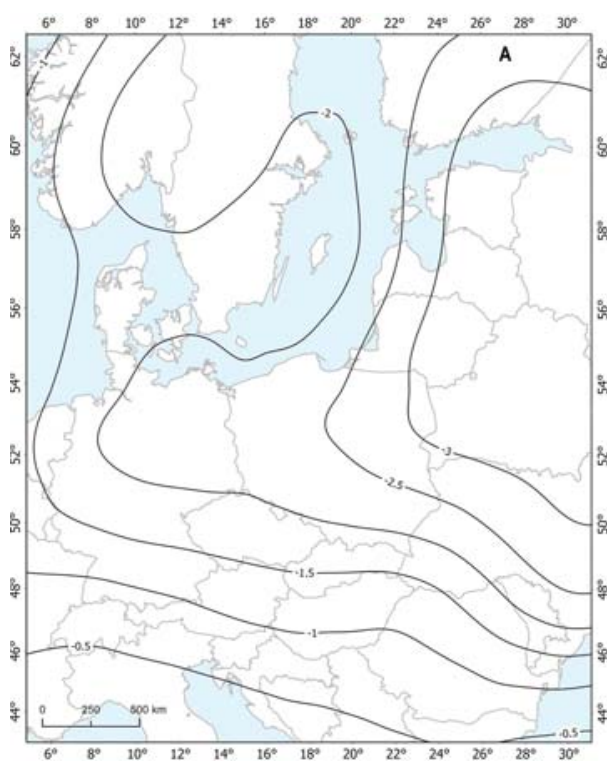

frequency of occurrence of very strong and extreme cold stress increases up to over $6 \%$ in the eastern part of the Baltic Sea coast and over most of the eastern part of Poland, probably due to the inflow of cold air from the north and the north-east. The inverse relationship was obtained in the case of the second couple mode in January (Fig. 6). The longitudinal decrease in the positive values of air temperature anomalies most probably reflects the warming impact of marine air due to the western air flow. Negative values of the analysed local variable anomaly indicate a decrease in the frequency of occurrence of cold stress of about 3\% in western regions to below $1 \%$ in the east. Canonical series are well correlated (0.91); however, the explained variance in the response field totals only approximately $7 \%$ and $8 \%$ of the air temperature field.

The data series covering the periods between 1951 and 1970 as well as 2001 and 2010 were used to validate the relationships demonstrated by the developed model. In January, the correlation coefficient between the reconstructed and observed

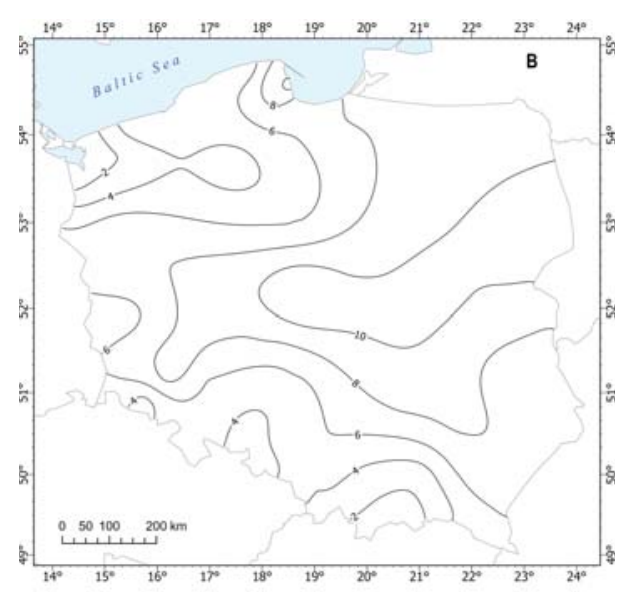

Figure 3. The first pair of canonical maps of the $2 \mathrm{~m}$ air temperature over the central Europe $(A)$ and the frequency of occurrence (\%) very strong and extreme cold stress based on the Universal Thermal Climate Index (UTCI) in Poland (B) in January, 1971-2000 

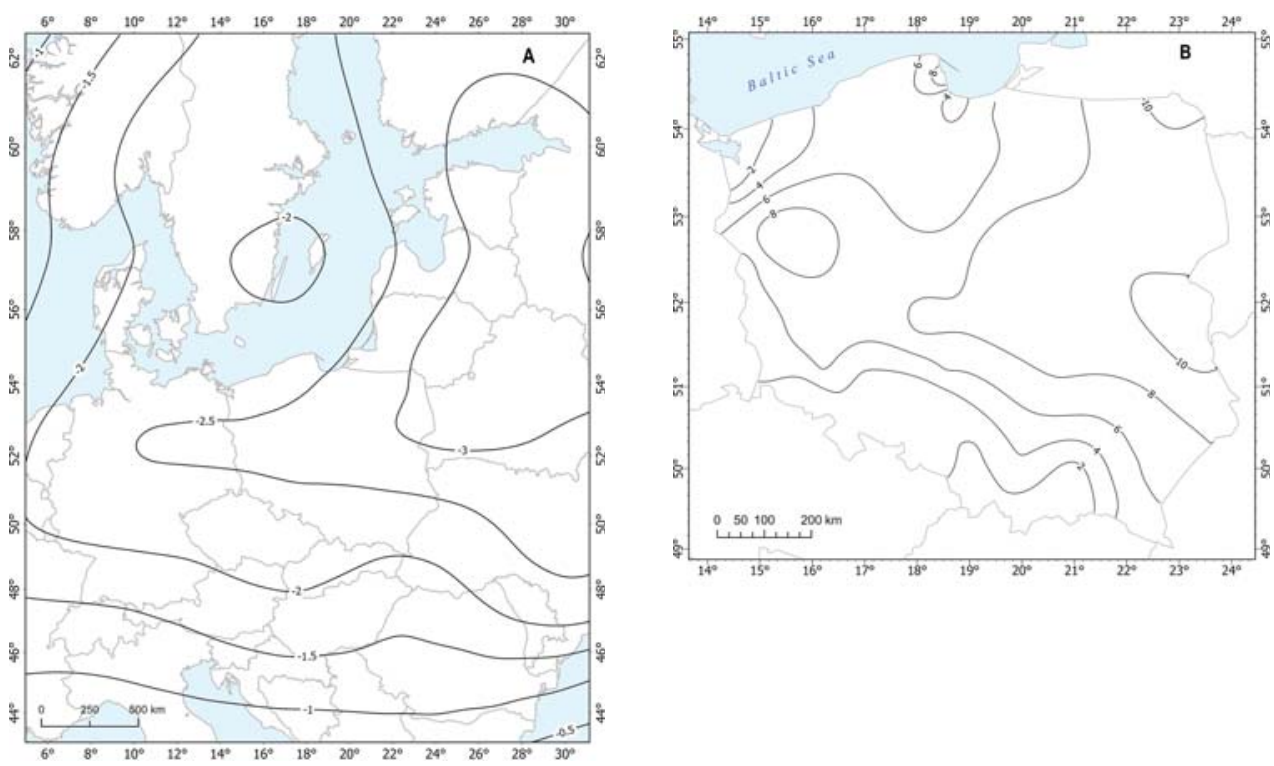

Figure 4. The first pair of canonical maps of the $2 \mathrm{~m}$ air temperature over the central Europe (A) and the frequency of occurrence (\%) very strong and extreme cold stress based on the Universal Thermal Climate Index (UTCl) in Poland (B) in February, 1971-2000
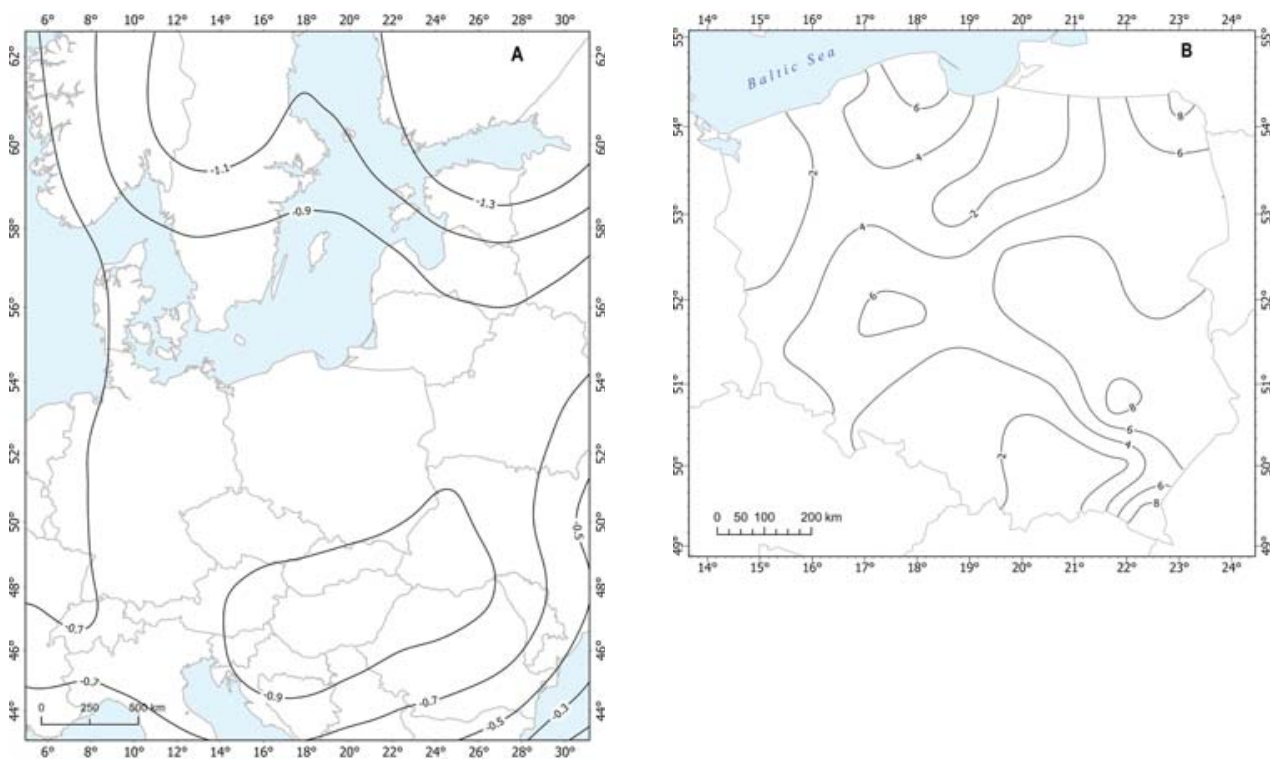

Figure 5. The first pair of canonical maps of the $2 \mathrm{~m}$ air temperature over the central Europe (A) and the frequency of occurrence (\%) very strong and extreme cold stress based on the Universal Thermal Climate Index (UTCl) in Poland (B) in December, 1971-2000 



Figure 6. The second pair of canonical maps of the $2 \mathrm{~m}$ air temperature over the central Europe (A) and the frequency of occurrence (\%) very strong and extreme cold stress based on the Universal Thermal Climate Index (UTCI) in Poland (B) in January, 1971-2000

time series varies from 0.1 in the central part of the coast to 0.8 on the coast of the Gulf of Gdańsk, north-eastern end of Poland and southwestern Poland; the mean value is 0.5 . The same mean value was obtained for February; however, the best results (up to over 0.7) can be observed in the east and in the southwestern Poland. The most reliable reconstruction on the whole area was obtained in December. The mean value of the correlation coefficient is 0.6 and the highest values (up to over 0.7 ) can be observed in the east and in the western part of central Poland. The mean monthly RMSE value in January totals 9.5\% (4.0 to 17.1\%), in February $10.3 \%$ (2.6 to $19.5 \%$ ), and in December $8.2 \%$ ( 4.1 to $13.0 \%$ ). The results show that the air temperature at $2 \mathrm{~m}$ over central Europe seems not to be an equally useful predictor throughout the area. The best quality model was obtained in eastern Poland, especially in the north-east and south-west of Poland. The results are the least useful in foothills of the Carpathians and on the central coast. Insufficient ability of the constructed model may result from the specificity of the analysed local element, the occurrence of which is also conditioned by other meteorological factors. Moreover, the analysed cold stress does not appear everywhere in every month of each winter season.

\section{Discussion and conclusions}

The results obtained in the present study show that the variability of near-surface air temperature over central Europe influences the frequency of occurrence of very strong and extreme cold stress among humans determined by the UTCI. The sign and the values of anomalies in the frequency of occurrence of the analysed variable in Poland clearly refer to the spatial variability of the anomaly in the monthly mean near-surface air temperature throughout central Europe. The greatest increase in the local variable is related to the occurrence of negative anomalies of regional variable with the highest values over north-eastern Europe. This pattern of air temperature field indicates an increase in the frequency of occurrence of analysed cold stress at 12 UTC all over 
Poland. In eastern Poland, the analysed cold stress may take about half of the days a month. Taking into account that the occurrence of cold stress was analysed only at midday, when the air temperature is usually not the lowest during the day, it should be concluded that the exposure of human body to the effects of cold stress may last longer. If very cold stress occurs at noon, it can be assumed that it could have occurred even more in the morning. Moreover, the regional variable is expressed by anomalies of monthly mean air temperature. Similar relationships between the forcing and the local variable would probably be obtained, if more values of UTCl were used. The near-surface air temperature negative anomalies presented in this work suggest the occurrence of a lower than usual air temperature over Poland due to the advection of cool air from the east, northeast, southeast or the north. More distant areas form a source of these cool air masses. The greatest decrease in air temperature usually falls on the areas where cold air flows are the earliest, e.g., in north-eastern Poland. Additionally, stagnant cold and dry air over the research area is conducive to the intense earth-surface radiation flux and a strong cooling of the surface. The influence of cold air advection on the thermal conditions in Poland were presented in previous works, most often in the context of atmospheric circulation. The occurrence of extremely low temperatures in central Europe in winter were mainly associated with anticyclonic types of circulation (Domonokos et al., 2003; Ustrnul et al., 2010). The variability of air temperature in winter primarily depends on the intensity or reduction of the zonal air flow. Weakening zonal circulation causes the advection of cold polar-continental air or even more cold arctic air masses favouring a strong decrease in the mean air temperature to over $3^{\circ} \mathrm{C}$ in south-eastern Poland (Bartoszek et al., 2017) and over $3.5^{\circ} \mathrm{C}$ in the north-eastern part of the country (Wójcik \& Miętus, 2012). Similar values of air temperature anomalies were obtained in the present work. Abnormal low values of air temperature often occurred during consecutive days in the form of cold waves. The occurrence of cold waves in central Europe is associated mainly with sustained anticyclonic situations blocking zonal circulation from the west (Pfahl, 2014; Tomczyk et al., 2019b). Above 30\% of the overall number of days with cold waves coincided with high pressure blocking situations and the highest number was observed in January (Porębska \& Zdunek, 2013). Many works reveal that high pressure atmospheric blocking may extend over a large area (e.g., Kyselý, 2008). The patterns of atmospheric circulation favouring cold air flow from the east and northeast, and the occurrence of cold waves were presented in many previous works (Wibig et al., 2009; Plavcová \& Kyselý, 2016; Tomczyk et al., 2019a). The influence of largescale near-surface air temperature on biometeorological conditions in Poland has been analysed only in relation to heat stress in summer (Owczarek, 2019). However, largescale atmospheric circulation patterns of the greatest importance for the occurrence of cold stress among humans in Poland were demonstrated in several previous works, but only at a regional scale. The circulation patterns favouring similar near-surface air temperature field to those presented in this work were identified in these studies. Very strong and extreme cold stress, under the UTCI, along the Polish coast occurs during cold air advection from the east and northeast over central Europe and during the presence of very cold air over northern Poland (Półrolniczak et al., 2016). Moreover, the influence of advection from the north-west was noticeable in the central part of the Polish coast as well as the air flow from the southeast in the eastern part. In turn, the extremely low UTCI values on the Polish coast were associated with the advection of cold air from the east and north-east over much of Europe as well as during air flow from the north over the Polish coast (Kolendowicz et al., 2018). The occurrence of very low UTCI values was also detected due to strong inflow of air masses from the west, favouring the increase of wind speed. It can be the evidence 
of the wind speed cooling impact on biometeorological conditions on the Baltic coast (Kolendowicz et al., 2018). The wind cooling effect in south-eastern Poland during the intensive north-western air flow was also highlighted (Bartoszek et al., 2017). The results of the present work also seem to confirm the synergistic effect of low air temperature and wind speed on the coast. Both the variability in the frequency of occurrence of very strong and extreme cold stress and the anomalies in individual CCA patterns do not clearly reflect the mitigating effect of the thermal activity of the Baltic Sea in winter, which is usually visible in the case of air temperature variability in Poland. One should also remember that the biometeorological conditions are also shaped by other factors (e.g., radiative, anemometric). Their impact can be varied depending on air temperature (Bröde et al., 2013). Moreover, meteorological elements are modified by the local modifications (e.g., local relief, land use). Despite the complexity of factors shaping the bioclimatic conditions, the results sufficiently reflect the important role of large-scale air temperature in shaping bioclimatic conditions in Poland in winter. Particularly, when negative anomalies are found over the area of eastern Europe and the Scandinavian Peninsula, which may indicate the possibility of cold air advection over the area of analysis. Abnormally low air temperature in winter can significantly modify the thermal environment and intensify cold stress among human beings. This relationship would also be revealed, if other biothermal indices were used, based on similar meteorological variables as UTCl, e. g. Physiologically Equivalent Temperature, PET (Matzarakis et al., 1999, 2010). However, particular indices provide different temperature thresholds with the same meaning of thermal stress (Błażejczyk et al., 2012). It can be assumed that the frequency of the range called very cold would be different than in the case of the UTCI index. For example, studies with the results based on the UTCl and PET in temperate climate were compared and showed the greatest differences in the winter period.
The UTCI values are lower and vary more considerably than PET for winter conditions. The values of UTCl can be even over $30^{\circ} \mathrm{C}$ lower than values of PET (Matzarakis et al., 2014). The frequency of very cold conditions under the PET scale can exceed $85 \%$ of cases, while there were no very cold evaluations of the UTCI (Chen \& Matzarakis, 2018). These differences mainly result from the different settings of clothing insulation used in modelling of these indices. Moreover, UTCl emphasizes the importance of the wind speed effects, while PET is more related to air temperature (Błażejczyk et al., 2012; Chen \& Matzarakis, 2018). Thus, the impact of negative values of air temperature anomalies on the increase in the frequency of the occurrence of very cold conditions under PET could be even more pronounced than in the case of the very strong and extreme cold stress of UTCl, but the confirmation of the above would require separate research. Taking into account the predicted changes in bioclimate, in view of this study, the results seem to be moderately reliable. The best reliability model was obtained in December. Generally, the study results are the most useful in the eastern part of Poland, in the south-west and on the eastern part of the coast. However, more meteorological variables should be used to predict future bioclimatic conditions. It can be concluded that the use of downscaling models allows to identify the main patterns of variables favouring the strongest cold stress in a human body. One can particularly be reminded that the observed increase in air temperature can be expressed by different changes in its statistical distribution (Wibig et al., 2009). This can constitute the evidence of the existing risk of very strong and extreme cold stress occurrence and its consequences also in the changing climate.

Editors' note:

Unless otherwise stated, the sources of tables and figures are the authors', on the basis of their own research. 


\section{References}

Barnett, T.P., Preisendorfer, R. (1987). Origins and levels of monthly and seasonal forecast skill for United States surface air temperatures determined by canonical correlation analysis. Monthly Weather Review, 115, 1825-1850. https://doi.org/10.1175/1520-0493(1987)115<1825:OALOMA>2.0.CO;2

Bartoszek, K., Wereski, S., Krzyżewska, A., Dobek, M. (2017). The influence of atmospheric circulation on bioclimatic conditions in Lublin (Poland). Bulletin of Geography, Physical Geography Series, 12, 41-49. https://doi.org/10.1515/bgeo-2017-0004

Benestad, R.E. (2002). Empirically downscaled temperature scenarios for northern Europe. Climate Research, 21, 105-125. https://doi.org/10.3354/cr021105

Błażejczyk, K. (2005). MENEX_2005 - the updated version of man - environment heat exchange model. https://www.igipz.pan.pl/tl_files/igipz/ZGiK/opracowania/indywidualne/blazejczyk/MENEX_2005.pdf [1 February 2021]

Błażejczyk, K., Baranowski, J., Błażejczyk, A. (2015b). Wpływ klimatu na stan zdrowia w Polsce: stan aktualny oraz prognoza do 2100 roku. Warsaw: Wydawnictwo Akademickie SEDNO.

Błażejczyk, K., Baranowski, J., Jendritzky, G., Błażejczyk, A., Bröde, P., Fiala, D. (2015a). Regional features of the bioclimate of Central and Southern Europe against the background of the Köppen-Geiger climate classification. Geographia Polonica, 88(3), 439-453. https://doi.org/10.7163/GPol.0027

Błażejczyk, K., Bröde, P., Fiala, D., Havenith, G., Holmér, I., Jendritzky, G., Kampmann, B., Kunert, A. (2010). Principles of the new Universal Thermal Climate Index (UTCI) and its application to bioclimatic research in European scale. Miscellanea Geographica, 14, 91-102.

https://doi.org/10.2478/mgrsd-2010-0009

Błażejczyk, K., Epstein, Y., Jendritzky, G., Staiger, H., Tinz, B. (2012). Comparison of UTCl to selected thermal indices. International Journal of Biometeorology, 56(3), 515-535.

https://doi.org/10.1007/s00484-011-0453-2

Błażejczyk, K., Jendritzky, G., Bröde, P., Fiala, D., Havenith, G., Epstein, Y., Psikuta, A., Kampmann, B. (2013). An introduction to the Universal Thermal Climate Index (UTCI). Geographia Polonica, 86(1), 5-10. https://doi.org/10.7163/GPol.2013.1

Błażejczyk, K., Kuchcik, M., Dudek, W., Kręcisz, B., Błażejczyk, A., Milewski, P., Szmyd, J., Pałczyński, C. (2016). Urban heat island and bioclimatic comfort in Warsaw. In F. Musco (Ed.) Counteracting urban heat island effects in a global climate change scenario. Springer International Publishing. https://doi.org/10.1007/978-3-319-10425-6_11

Błażejczyk, K., Kunert, A. (2011). Bioklimatyczne uwarunkowania rekreacji i turystyki w Polsce. Monografie, 13, Warsaw: IGiPZ PAN.

Błażejczyk, K., Nejedlik, P., Skrynyk, O., Halaś, A., Błażejczyk, A., Mikulova, K. (2020). Influence of geographical factors on thermal stress in northern Carpathians. International Journal of Biometeorology, Special Issue: UTCl - 10 years of applications. https://doi.org/10.1007/s00484-020-02011-x

Błażejczyk, M., Błażejczyk, K. (2006). Bioklima ver. 2.6. Software (2010). https://www.igipz.pan.pl/Bioklima-zgik.html [1 February 2021]

Bröde, P., Fiala, D., Błażejczyk, K., Holmer, I., Jendritzky, G., Kampmann, B., Tinz, B., Havenith, G. (2012). Deriving the operational procedure for the Universal Thermal Climate Index (UTCI). International Journal of Biometeorology, 56(3), 481-449. https://doi.org/10.1007/s00484-011-0454-1

Bröde, P., Krüger, E.L., Fiala, D. (2013). UTCl: validation and practical application to the assessment of urban outdoor thermal comfort. Geographia Polonica, 86(1), 11-20. https://doi.org/10.7163/GPol.2013.2

Bryś, K., Ojrzyńska, H. (2016). Bodźcowość warunków biometeorologicznych we Wrocławiu (Stimulating qualities of biometeorological conditions in Wrocław). Acta Geographica Lodziensia, 104, 193-200. 
Busuioc, A., Tomozeiu, R., Cacciamani, C. (2008). Statistical downscaling model based on canonical correlation analysis for winter extreme precipitation events in the Emilia-Romagna region. International Journal of Climatology, 28, 449-464. https://doi.org/10.1002/joc.1547

Cattiaux, J., Vautard, R., Cassou, C., You, P., Masson-Delmotte, V., Codron, F. (2010). Winter 2010 in Europe: A cold extreme in a warming climate. Geophysical Research Letters, 37, L20704. https://doi.org/10.1029/2010GL044613

Chen, YC., Matzarakis, A. (2018). Modified physiologically equivalent temperature-basics and applications for western European climate. Theoretical and Applied Climatology, 132, 1275-1289. https://doi.org/10.1007/s00704-017-2158-x

Di Napoli, C., Pappenberger, F., Cloke, H.L. (2018). Assessing heat-related health risk in Europe via the Universal Thermal Climate Index (UTCI). International Journal of Biometeorology, 62(7), 1155-1165. https://doi.org/10.1007/s00484-018-1518-2

Domonokos, P., Kysely, J., Piotrowicz, K., Petrovic, P., Likso, T. (2003). Variability of extreme temperature events in southcentral Europe during the 20th century and its relationship with large-scale circulation. International Journal of Climatology, 23, 987-1010. https://doi.org/10.1002/joc.929

Fiala, D., Havenith, G., Bröde, P., Kampmann, B., Jendritzky, G. (2012). UTCI Fiala multi-node model of human heat transfer and temperature regulation. International Journal of Biometeorology, 56, 429441. https://doi.org/10.1007/s00484-011-0424-7

Fröhlich, D., Matzarakis, A. (2020). Calculating human thermal comfort and thermal stress in the PALM model system 6.0. Geoscientific Model Development, 13, 3055-3065.

Gasparrini, A., Guo, Y., Hashizume, M., Lavigne, E., Zanobetti, A., Schwartz, J., Tobias, A., Tong, S., Rocklöv, J., Forsberg, B., Leone, M., De Sario, M., Bell, M.L., Guo, Y.L.L., Wu, Ch., Kan, H., Yi, S-M., de Sousa Zanotti Stagliorio Coelho, M., Saldiva, P.H.N.,... Armstrong, B. (2015). Mortality risk attributable to high and low ambient temperature: a multicountry observational study. Lancet, 386, 369-375. https://doi.org/10.1016/S0140-6736(14)62114-0

Ge, Q., Kong, Q., Xi, J., Zheng, J. (2017). Application of UTCl in China from tourism perspective. Theoretical and Applied Climatology, 128, 551-561. https://doi.org/10.1007/s00704-016-1731-z

Geletič, J., Lehnert, M., Krč, P., Resler, J., Krayenhoff, E.S. (2021). High-resolution modelling of thermal exposure during a hot spell: A case study using PALM-4U in Prague, Czech Republic. Atmosphere, 12(2), 175. https://doi.org/10.3390/atmos12020175

Głogowski, A., Bryś, K., Perona, P. (2020). Bioclimatic conditions of the Lower Silesia region (South-West Poland) from 1966 to 2017. International Journal of Biometeorology, Special Issue: UTCI - 10 years of applications. https://doi.org/10.1007/s00484-020-01970-5

Holmér, I. (1988). Assessment of cold stress in terms of required clothing insulation - IREQ. International Journal of Industrial Ergonomics, 3(2),159-166. https://doi.org/10.1016/0169-8141(88)90017-0

Jendritzky, G., de Dear, R., Havenith, G. (2012). UTCl - why another thermal index? International Journal of Biometeorology, 56(3), 421-428. https://doi.org/10.1007/ s00484-011-0513-7

Kalnay, E., Kanamitsu, M., Kistler, R., Collins, W., Deaven, D., Gandin, L., Iredell, M., Saha, S., White, G., Woolen, J., Zhu, Y., Chelliah, M., Ebisuzaki, W., Higgins, W., Janowiak, J., Mo, K.C., Ropelewski, C., Wang, J., Leetmaa, A., Reynolds, R., Jenne, R., Joseph, D. (1996). The NCEP/NCAR 40-year reanalysis project. Bulletin of the American Meteorology Society, 77, 437-470.

https://doi.org/10.1175/1520-0477(1996)077<0437:TNYRP>2.0.CO;2

Keatinge, W.R. (2002). Winter mortality and its causes. International Journal of Circumpolar Health, 61(4), 292-299. https://doi.org/10.3402/ijch.v61i4.17477

Kolendowicz, L., Półrolniczak, M., Szyga-Pluta, K., Bednorz, E. (2018). Human biometeorological conditions in the southern Baltic coast based on the Universal Thermal Climate Index (UTCI). Theoretical and Applied Climatology, 134, 363-379. https://doi.org/10.1007/s00704-017-2279-2

Krüger, E.L., Vieira Silva, T.J., da Silveira Hirashima, S.Q., Grala da Cunha, E., Alcântara, R.L. (2020). Calibrating UTCI'S comfort assessment scale for three Brazilian cities with different climatic conditions. 
International Journal of Biometeorology, Special Issue: UTCI - 10 years of applications. https://doi.org/10.1007/s00484-020-01897-x

Krzyżewska, A., Wereski, S., Dobek, M. (2020). Summer UTCl variability in Poland in the twenty-first century. International Journal of Biometeorology, Special Issue: UTCI - 10 years of applications. https://doi.org/10.1007/s00484-020-01965-2

Kuchcik, M. (2017). Warunki termiczne w Polsce na przełomie XX i XXI wieku i ich wpływ na umieralność. Prace Geograficzne, 263, Warsaw: IGiPZ PAN.

Kuchcik, M. (2020). Mortality and thermal environment (UTCI) in Poland - long-term, multi-city study. International Journal of Biometeorology, Special Issue: UTCI - 10 years of applications https://doi.org/10.1007/s00484-020-01995-w

Kuchcik, M., Błażejczyk, K., Halaś, A. (2021). Long-term changes in hazardous heat and cold stress in humans: multi-city study in Poland. International Journal of Biometeorology, Special Issue: UTCI - 10 years of applications. https://doi.org/10.1007/s00484-020-02069-7

Kyselý, J. (2008). Influence of the persistence of circulation patterns on warm and cold temperature anomalies in Europe: Analysis over the 20th century. Global and Planetary Change, 62, 147-163. https://doi.org/10.1016/j.gloplacha.2008.01.003

Laschewski, G., Jendritzky, G. (2002). Effects of the thermal environment on human health: an investigation of 30 years of daily mortality data from SW Germany. Climate Research, 21(1), 91-103. https://doi.org/10.3354/cr021091

Lehnert, M., Tokar, V., Jurek, M., Geletič, J. (2020). Summer thermal comfort in Czech cities: measured effects of blue and green features in city centres. International Journal of Biometeorology. https://doi.org/10.1007/s00484-020-02010-y

Lhotka, O., Kyselý, J. (2015). Characterizing joint effects of spatial extent, temperature magnitude and duration of heat waves and cold spells over Central Europe. International Journal of Climatology, 35(7),1232-1244. https://doi.org/10.1002/joc.4050

Maak, K., von Storch, H. (1997). Statistical downscaling of monthly mean air temperature to the beginning of flowering of Galanthus nivalis L. in Northern Germany International Journal of Biometeorology, 41, 5-12. https://doi.org/10.1007/s004840050046

Matulla, C., Scheifinger, H., Menzel, A., Koch, E. (2003). Exploring two methods for statistical downscaling of Central European phenological time series. International Journal of Biometeorology, 48(2), 56-64. https://doi.org/10.1007/s00484-003-0186-y

Matzarakis, A., Mayer, H., Iziomon, M.G. (1999). Applications of a universal thermal index: physiological equivalent temperature. International Journal of Biometeorology, 43, 76-84. https://doi.org/10.1007/s004840050119.

Matzarakis, A., Muthers, S., Rutz, F. (2014). Application and comparison of UTCl and PET in temperate climate conditions. Finisterra, 49(98), 21-31. https://doi.org/10.18055/Finis6453

Matzarakis, A., Rutz, F., Mayer, H. (2010). Modelling radiation fluxes in simple and complex environments: basics of the RayMan model. International Journal of Biometeorology, 54, 131-139. https://doi.org/10.1007/s00484-009-0261-0

Milewski, P. (2013). Application of the UTCI to the local bioclimate of Poland's Ziemia Kłodzka region. Geographia Polonica, 86, 47-54. https://doi.org/10.7163/GPol.2013.6

Novak, M. (2013). Use of the UTCI in the Czech Republic. Geographia Polonica, 86, 21-28. https://doi.org/10.7163/GPol.2013.3

Nowosad, M., Rodzik, B., Wereski, S., Dobek, M. (2013). The UTCl index in Lesko and Lublin and its circulation determinants. Geographia Polonica, 86, 29-36. https://doi.org/10.7163/GPol.2013.4

Okoniewska, M. (2020). Daily and seasonal variabilities of thermal stress (based on the UTCI) in air masses typical for Central Europe: an example from Warsaw. International Journal of Biometeorology, Special issue: UTCl - 10 years of applications. https://doi.org/10.1007/s00484-020-01997-8 
Owczarek, M., Filipiak, J. (2016). Contemporary changes of thermal conditions in Poland, 1951-2015. Bulletin of Geography. Physical Geography Series, 10, 31-50. https://doi.org/10.1515/bgeo-2016-0003

Owczarek, M. (2019). The influence of large-scale factors on the heat load on human beings in Poland in the summer months. Theoretical and Applied Climatology, 137(1-2), 855-869. https://doi.org/10.1007/s00704-018-2633-z

Petralli, M., Massetti, L., Pearlmutter, D., Brandani, G., Messeri, A., Orlandini, S. (2020). UTCl field measurements in an urban park in Florence (Italy). Miscellanea Geographica, 24(3), 111-117. https://doi.org/10.2478/mgrsd-2020-0017

Pfahl, S. (2014). Characterising the relationship between weather extremes in Europe and synoptic circulation features. Natural Hazards and Earth System Sciences, 14, 1461-1475. https://doi.org/10.5194/nhess-14-1461-2014

Plavcová, E., Kyselý, J. (2016). Overly persistent circulation in climate models contributes to overestimated frequency and duration of heat waves and cold spells. Climate Dynamics, 46(9-10), 2805-2820. https://doi.org/10.1007/s00382-015-2733-8

Porębska, M., Zdunek, M. (2013). Analysis of extreme temperature events in Central Europe related to high pressure blocking situations in 2001-2011. Meteorolologische Zeitschrift, 22(5), 533-540. https://doi.org/10.1127/0941-2948/2013/0455

Półrolniczak, M., Szyga-Pluta, K., Kolendowicz, L. (2016). Bioklimat wybranych miast pasa Pobrzeży Południowobałtyckich na podstawie uniwersalnego wskaźnika obciq̨żenia cieplnego. Acta Geographica Lodziensia, 104, 147-161.

Provençal, S., Bergeron, O., Leduc, R., Barrette, N. (2016). Thermal comfort in Quebec City, Canada: sensitivity analysis of the UTCl and other popular thermal comfort indices in a mid-latitude continental city. International Journal of Biometeorology, 60(4), 591-603. https://doi.org/10.1007/s00484-015-1054-2

Santos, J., Corte-Real, J., Ulbrich, U., Palutikof, J. (2007). European winter precipitation extremes and large-scale circulation: A coupled model and its scenarios. Theoretical and Applied Climatology, 87, 85-102. https://doi.org/10.1007/s00704-005-0224-2

Santos, J.A., Malheiro, A.C., Pinto, J.G., Jones, G.V. (2012). Macroclimate and viticultural zoning in Europe: observed trends and atmospheric forcing. Climate Research, 51, 89-103. https://doi.org/10.3354/cr01056

Staiger, H., Laschewski, G., Matzarakis, A. (2019). Selection of appropriate thermal indices for applications in human biometeorological studies. Atmosphere,10(1), 18. https://doi.org/10.3390/atmos10010018

Tomczyk, A.M., Bednorz, E., Półrolniczak, M., Kolendowicz, L. (2019a). Strong heat and cold waves in Poland in relation with the large-scale atmospheric circulation. Theoretical and Applied Climatology, 137(3-4), 1909-1923. https://doi.org/10.1007/s00704-018-2715-y

Tomczyk, A.M., Bednorz, E., Sulikowska, A. (2019b). Cold spells in Poland and Germany and their circulation conditions. International Journal of Climatology, 39, 4002-4014. https://doi.org/10.1002/joc.6054

Tomczyk, A.M., Bednorz, E., Szyga-Pluta, K. (2021). Changes in air temperature and snow cover in winter in Poland. Atmosphere, 12(1), 68. https://doi.org/10.3390/atmos12010068

Tomczyk, A.M., Owczarek, M. (2020). Occurrence of strong and very strong heat stress in Poland and its circulation conditions. Theoretical and Applied Climatology, 139(3-4), 893-905. https://doi.org/10.1007/s00704-019-02998-3

Tomozeiu, R., Pasqui, M., Quaresima, S. (2018). Future changes of air temperature over Italian agricultural areas: a statistical downscaling technique applied to 2021-2050 and 2071-2100 periods. Meteoro/ogy and Atmospheric Physics, 130, 543-563. https://doi.org/10.1007/s00703-017-0536-7

Urban, A., Kyselý, J. (2014). Comparison of UTCI with other thermal indices in the assessment of heat and cold effects on cardiovascular mortality in the Czech Republic. International Journal of Environmental Research and Public Health, 11, 952-967. https://doi.org/10.3390/ijerph110100952 
Ustrnul, Z., Czekierda, D., Wypych, A. (2010). Extreme values of air temperature in Poland according to different atmospheric circulation classifications. Physics and Chemistry of the Earth, 35, 429-436. https://doi.org/10.1016/j.pce.2009.12.012

Vinogradova, V. (2020). Using the Universal Thermal Climate Index (UTCI) for the assessment of bioclimatic conditions in Russia. International Journal of Biometeorology, Special issue: UTCI - 10 years of applications. https://doi.org/10.1007/s00484-020-01901-4

von Storch, H., Zwiers, F.W. (1999). Statistical analysis in climate research. Cambridge: Cambridge University Press. https://doi.org/10.1017/CBO9780511612336

Wereski, S., Krzyżewska, A., Dobek, M. (2020). Winter UTCI variability in Poland in the 21st century. Miscellanea Geographica, 24(3), 128-137. https://doi.org/10.2478/mgrsd-2020-0021

Werner, P.C., von Storch, H. (1993). Interannual variability of Central European mean temperature in January-February and its relation to large-scale circulation. Climate Research, 3, 195-207.

Wibig, J. (2007). Fale ciepła i chłodu w Środkowej Polsce na przykładzie Łodzi. Acta Universitatis Lodziensis, Folia Geographica Physica, 8, 27-61. http://hdl.handle.net/11089/2852

Wibig, J., Podstawczyńska, A., Rzepa, M., Piotrowski, P. (2009). Cold waves in Poland - frequency, trends, and relationships with atmospheric circulation. Geographia Polonica, 82, 47-59.

Wilks, D.S. (2005). Statistical methods in the atmospheric sciences. International Geophysics Series. Burlington: Elsevier.

Wójcik, R., Miętus, M. (2012). Rola cyrkulacji atmosferycznej w kształtowaniu długookresowych zmian temperatury powietrza w Polsce. In Z. Bielec-Bakowska, E. Łupikasza, A. Widawski (Eds.), Rola cyrkulacji atmosfery w kształtowaniu klimatu (pp. 385-397), Sosnowiec: Wydział Nauk o Ziemi Uniwersytetu Ślquskiego. 